\title{
The Liability of the Witness for His Wrongful Action under the Jordanian Civil Law
}

\author{
Mamoun Al-Hunaiti ${ }^{1}$ \\ ${ }^{1}$ Middle East University, Amman, Jordan \\ Correspondence: Mamoun Al-Hunaiti, Middle East University, Amman, Jordan. E-mail: \\ mamoon_hunaity@yahoo.com
}

Received: May 23, 2018

Accepted: June 11, $2018 \quad$ Online Published: August 30, 2018

doi:10.5539/jpl.v11n3p111

URL: https://doi.org/10.5539/jpl.v11n3p111

\begin{abstract}
The civil liability of the witness in the Jordanian civil law arises when the witness commits an unlawful act, results in harm to others. Such damage would not have occurred without the unlawful act of the witness. The unlawful act of the witness arises when he performs a false statement, fails to appear to give his statement, to appear in the Judicial council refuses to answer the questions asked by the Judicial session, or perform his statement despite the existence of a legal matter that forbid him from giving it .
\end{abstract}

\section{Introduction}

\subsection{The Subject of the Study}

This study discusses the civil liability of the witness in the Jordanian civil law. The witness is a natural person who attends the Judicial session to perform his testimony on a specific matter or matters. He must say the truth without modification (no less no more), however, human being could not be infallible to commit errors and his testimony may result in unlawful acts causing harm to one of the proceeding parties. Therefore, his civil liability arises. Hence, this study deals with the civil liability of the witness in all its aspects, and to know when this liability arises and when it does not exist.

\subsection{The Importance of the Study}

This is the first study that deals with the subject of civil liability of the witness. This topic is a significant one to many groups of society, especially judges, lawyers, professors and students of faculties of law and witnesses. As it examines all aspects of the civil liability of the witness and seeks to show the shortcoming of this regulation.

\subsection{The Objectives of the Study}

This study aims to identify the unlawful act of the witness, his harmful acts and when his civil liability arises. The study defines the witness and distinguish him from others and show his role serving the justice.

\subsection{Study Problem}

When does the civil liability of the witness for his unlawful act arise and when it disappears?

\subsection{The Study Questions}

- What are the unlawful acts of the witness? What is the basis of his liability? When do we consider the act of the witness legitimate or permissible, and what is the extent of his liability for his unlawful conduct?

\subsection{Study Methodology}

This study adopts the analytical method, which will analyze the legal terms related to it and the judicial rulings, if any, the studies and jurisprudential opinions that have been exposed to this subject.

\subsection{Study Plan}

In order to understand the harmful act of the witness, it is necessary to define the witness and to address his harmful acts. Hence, this research is divided into two chapters: the first is related to definition of the witness, and the second deals with the harmful act of the witness. However, the conclusion includes the summary and recommendations. 


\section{Nature of Witness}

The nature of witness arises by defining its meaning, distinguishing it from similar terms, and indicating the importance of its role in achieving justice. We consider each of these sections separately as follows:

\subsection{Definition of Witness}

The Jordanian legislator leaves the matter of defining a witness to the jurisprudence and the judiciary. The laws, including civil or penal laws has no specific definition of witness ${ }^{1}$. The Jordanian judiciary, whether civil, criminal, Sharia or administrative, does not include any provision defining witness ${ }^{2}$. However, the jurisprudence has provided more than a definition for witness, expressing its nature. The definitions provided by the jurisprudence are as follows:

- The witness is the person who tells the court what he saw or heard, or the information heard from others about a certain incident ${ }^{3}$.

- A witness is someone who tells what he knows personally, either from what he saw or what he heard ${ }^{4}$.

- The witness who swears the oath, before disclosing the fact he saw, heard or generally understood by his senses ${ }^{5}$.

- A witness is a person who attended the Judiciary session and swore oath, and then he said something of a person right against another or an incident that he saw or heard or is under his knowledge ${ }^{6}$.

It is noted from the aforementioned definitions of a witness, that all definitions are considered of the same concept in terms of that they all treat the witness as the person who tells or to witness an event he saw , or heard it himself or by others. Actually, reaching a definite, strict definition of a witness is extremely difficult and requires high precision that the witness in a penal lawsuit is differs from the witness in the civil, administrative or personal status cases. Not only that but it differs from the witness in the disciplinary councils, whether he is a witness for the public right or a witness for defense. Despite these difficulties, the witness can be defined as: "a natural person who attends to the Judicial session, before a prosecutor, criminal court, court of law, administrative court, constitutional court, labor court, or a disciplinary court (a disciplinary board) And this person who the law permits to hear his testimony, therefore he will say the oath determined by law, and then state information, about an incident that he was called to testify, and whether the source of that information was what he saw or was aware in any senses or heard from others).

We believe that this definition expresses the meaning of a witness, regardless of what is the case he attests, or the authority receives his testimony.

Nevertheless, it would be highly required by the Jordanian legislator, especially the Evidence Law, as it is the law of proof in general, to reach a strict, precise definition of the witness.

\subsection{The Witness Shall Be Distinguished from Similar Terms}

There may some cases where confusion may arise between the concept of the witness and other terms that may seem similar to it. The similarity is highlighted in terms of the performance of the legal oath, as some people think that each person swears before the judge is considered a witness, which may create the confusion. Not everyone swears oath before the judge is considered as a witness. Whether he is a complainant, a plaintiff, an expert or a Syndic.

In order to remove this confusion about these concepts, and to show the differences between the witness and these terms, we deal with it as follows:

\subsubsection{The Witness and the Complainant}

A witness is a person who gives his testimony about a particular incident, in civil, criminal or other lawsuit, without being a litigant or a party to the case in which he or she is giving his testimony. The complainant is the victim, the opponent and a party in the case, and when the general prosecutor hears his testimony it is heard on

\footnotetext{
${ }^{1}$ These laws are as follows: Civil Law No. 43 of 1976, the Evidence Law and its amendments No. 30 of 1952, the Civil Procedure Code and its amendments No. 24 of 1988 and the Code of Criminal Procedure and its amendments No. 9 of 1961.

${ }^{2}$ This is what has been proven to us through Adalah's information systems program.

${ }^{3}$ Abdel Rahman Bakush, evidence of evidence in the Algerian law and Islamic jurisprudence, a theoretical and applied study, publications of the National Book Foundation, Algeria, 3, 1998, p. 189.

${ }^{4}$ Musa Nafi, Explanation of the Jordanian Evidence Law, without publishing house, Amman, 2008, p99.

${ }^{5}$ Yehia Hassanein, Evidence in the Algerian Civil Code, Publications of the National Book Foundation, 1997, p. 283.

${ }^{6}$ Suad Al-Douri, Certificate in Islamic Law and Status Laws, Master's Thesis, Faculty of Law, University of Babylon, 1997, p. 25.
} 
the basis that it is a witness to the public right ${ }^{7}$.

Therefore, it is possible for the complainant to hold the status of a witness and complainant in the same case. Whereas the witness has only the status of a witness, and his role ends as soon as the court hears his testimony. The complainant role ends when the case is settled.

\subsubsection{The Witness and Plaintiff}

The witness differs from the plaintiff in the civil case, as he does not have an interest or purpose. His object is to say the truth. Regardless of the beneficiary of his testimony, whether plaintiff or defendant, he is not an opponent or a disputing party in the case. However the plaintiff has an interest in the case, and who aims to obtain a judicial rule, and he is the person who claims a right in terms of determination or protection ${ }^{8}$.

It is understood that the plaintiff will swear the oath in the lawsuit, and when doing that he is not considered as a witness, but he remains a plaintiff and holds the capacity of plaintiff only, without extending this capacity to hold a capacity of a witness. The plaintiff when swearing the oath, his testimony is considered a decisive or complementary oath ${ }^{9}$. Therefore, the oath of the plaintiff does not mean that he is considered as a witness in the case, and swearing the oath does not change his position or his status in the case.

\subsubsection{The Witness and the Judicial Expert}

Although the judicial expert swear the legal oath before the judge or the general prosecutor, this does not change his status in the case, and makes him a witness. There is significant differences between him and the witness. The witness provides the judge with information obtained by the sensory observation, while the expert presents the judge with opinions, assessments and judgments reached by applying scientific laws and technical tools. Also, the witnesses are determined and cannot be replaced by others. The number of experts are unlimited, and the judge has the right to elect whoever he wants and can replace them ${ }^{10}$. Also the formula of the oath presented by both is different, the roles and missions of both are different, and the conditions and duties of both are different also.

\subsubsection{The Witness and the Syndic ${ }^{11}$}

The Syndic is the commissioner of the bankruptcy, and the agent of bankruptcy. He is a natural person appointed by the court, who holds estate of the bankrupt. Therefore, he is a paid agent, and when he is appointed, he swears before the court to perform his duties honestly and faithfully. Therefore, his oath does not make him a witness. He can also be replaced and his duties and roles in the case are completely different from the role and duties of the witness.

\subsection{The Importance of the Role of the Witness in Achieving Justice}

The witness when appears before the Judicial session to give his testimony shall say the truth, the whole truth and nothing else without abuse of falsification and modification. the witness is not a litigant in the case or has a particular interest or purpose. But he is a servant of justice and was requested or summoned to give his testimony in an incident, and inform the court of certain facts about it, seen or heard or recognized by his senses, or came to his knowledge. The significance of the witness and his testimony is illustrated by the following:

1) Evidence of witnesses is the first place in penal, commercial, legal and religious articles ${ }^{12}$.

2) Witness testimony is a reliable evidence of judicial decisions ${ }^{13}$.

3) Witness testimony is sometimes the only evidence in a criminal case ${ }^{14}$.

\footnotetext{
${ }^{7}$ Mohammed Sobhi Najm, Code of Criminal Procedure, Dar al-Thaqafa, Amman, I, First Edition, 2000, p. 66.

${ }^{8}$ Awad Ahmed Al-Zu'bi, Principles of Civil Trials, Dar Wael Publishing, Amman, 1, 2003, pp. 391-392.

${ }^{9}$ The decisive right is directed by one of his opponents to resolve the dispute, or the court understands that the opponent has the right to direct the oath to his opponent when he cannot prove his claim or party, the right is complementary is directed by the case or the value of what governs provided that it is not The case is a complete guide, and the case is not free of any evidence. See Articles 53 and 70 of the Jordanian Evidence Act.

${ }^{10}$ Mustafa Abdel-Jawad Hijazi, Civil Liability of the Judicial Expert, New University House, Alexandria, 204, p. 17 and what us after it.

${ }^{11}$ About the provisions of the Syndic (agent of bankruptcy) See Articles (338-345) of the Jordanian Trade Law No. 12 of 1966.

${ }^{12}$ Siliman Mark, The Origins of Evidence and its Procedures in the Civil Materials in Egyptian Law, in Comparison with the Techniques of the Arab Countries, Part Two, The Restricted Evidence and What Can Be Proven in Writing, Dar Al-Jil for Printing, Cairo, 1986, p.311.

${ }^{13}$ Abdul Razzaq Al-Sanhoury, The Mediator in Explaining the Civil Law, Part II The Theory of Commitment in General, Evidence, Implications of Commitment, Dar Al-Arabiya Revival Beirut, No Publication Year, p. 311.

${ }^{14}$ Abdelhamid Al-Shawarbi, Evidence of Witnesses in Civil, Commercial, Criminal and Personal Status, Knowledge Establishment, Alexandria, 1996, p. 351.
} 
4) Many of the judgments of innocence or conviction depend on witness testimony ${ }^{15}$.

5) A crime sometimes has no evidence due to absence of a witness ${ }^{16}$.

6) Testimony of witnesses is the pillar of proof, and the witness is the eye and ears of the court ${ }^{17}$.

7) Through witness testimony, an innocent person may be convicted on the basis of perjury, or discharged criminal who committed an offense for deliberately changing the testimony ${ }^{18}$.

8) Testimony of witnesses is the predominant evidence, and other evidence may not reach the witness testimony ${ }^{19}$ through which the right is clarified or not ${ }^{20}$. The truthfulness of the allegation is evident from his lie $^{21}$ and the facts are revealed from the ambiguity or confusion ${ }^{22}$.

The above clarifies the significance of testimony witnesses, as it may serves the justice, when witnesses says the truth but it may be harmful and destructive to justice when tampering witnesses, and giving a false statement .

\section{The Wrongful Act of the Witness}

When a witness performs his testimony, he may commit an unlawful act, resulting injury to third parties, and if an unlawful act is not committed, the third party will not be harmed. When such an event occurs, the civil liability of the witness will rise in this area. The liability that arises in this respect is not the contractual liability for the absence of the contractual bond between the witness and the victim. On the other hand, the liability that arises here is the liability for the unlawful act. In order to clear this liability, we must present its purpose, elements, and its scope. For this purpose, we divide this chapter into three sections:

\subsection{The Concept of the Unlawful Act of the Witness}

The unlawful act is considered an element of the commitment elements ${ }^{23}$ it is one of the most important and most common of these elements, and prevalent in addition to the contract. The unlawful act is the same as the negligent liability, but the Jordanian legislator preferred to designate the unlawful act instead of the negligent liability, since the designation of the unlawful act is a term derived from the Islamic jurisprudence (Fiqh) ${ }^{24}$.

The Jordanian legislature, through the Civil Code, regulated the provisions of liability for the unlawful act in general and specifically through articles (256-292). We generally mean that he did not specify provisions or articles on liability for the unlawful act of doctors, engineers and others, including witnesses, and merely provided general provisions applicable to all without distinction or exception. It should be noted that the legal regulation established and prescribed by the Jordanian legislator for liability for the unlawful act is meticulous and orderly and covers all aspects of the unlawful act, whether due to personal actions or the act of others or things or animals in addition to the rape and encroachment. We are concerned about the special regulation of liability of personal acts, which helps to measure, drop and apply them to the witness who committed the unlawful act. To achieve this intention and to firmly evaluate the liability of the witness for the unlawful act, i.e. when it is committed we shall present the meaning of the concept of the liability of the witness for the unlawful act and the elements of liability for that act are as follows:

\subsubsection{The Meaning of the Liability of the Witness for Its Unlawful (Wrongful) Act}

We know that the unlawful act or also called negligent liability is one of the sources of obligation, which is one of the most important and most common sources of the contract. As we mentioned earlier we will talk only about

\footnotetext{
${ }^{15}$ Jamil Cherkaoui, Evidence in Civil Materials, Dar al-Nahda al-Arabiya, Cairo, 1983, 120.

${ }^{16}$ Glil Gregg, The General Theory of Obligations, Part III in Proof of Obligations (The System of Evidence), Al-Saad Newspaper, Beirut, 1960, p. 136.

${ }^{17}$ Soldier Abdul Malik, Criminal Encyclopedia, Part I (Trading, subscription), the Egyptian Book House, Cairo, 1931, p. 124.

${ }^{18}$ Edwar Eid, Encyclopedia of the Foundations of Trials, Evidence and Implementation, Part Sixteen, Proof (Right and Testimony), Without Publishing House, Lebanon, 1991, p.165.

${ }^{19}$ Anwar Sultan, Rules of Evidence in Civil and Commercial Law, Study in the Egyptian and Lebanese Laws, University House, Beirut, 1984, p.5.

${ }^{20}$ Ahmed Nashat, the anchor of evidence, the first part, the pillars of evidence, the burden of proof, methods of proof, writing, witness testimony, Arab Thought House, Cairo, I 7, 1972, p.29.

${ }^{21}$ Izz al-Din al-Dinasuri, and Hamid Abdul Hakim Akkaz, Commentary on the Law of Evidence, World of Books, Cairo, I 2, 1977 , p. 101.

${ }^{22}$ Mohamed Attia Ragheb, The General Theory of Evidence, Knowledge Press, Cairo, 1960, p.62.

${ }^{23}$ The Jordanian legislator preferred to choose the name of the harmful act instead of naming the tortuous responsibility prevailing in the civil law of Egypt, Syria, Iraq and Lebanon Algeria, Tunisia, Morocco and Libya, and the cause of the Jordanian legislator in what he went from naming, that the designation of the malicious act is derived from Islamic jurisprudence.

${ }^{24}$ Adnan Al-Sarhan, Nuri Khater, Explanation of Civil Law, op. Cit., Pp. 363 and 364.
} 
unlawful act within the scope of personal acts only. Is the general rule in the liability for personal acts is established and promoted when a previous legal obligation to derogate from third parties has been violated? Which arises and stands out when a breach of a previous legal obligation imposes, obliges him not to commit and defy such breach, yet he committed it. The content of the obligation here is not to cause unlawful harm to others but to do so. Therefore the damage which is characterized as illegitimacy or illegality is the source and origin of its liability. In other words, during the performance of the testimony, the witness, in violation of the legislator's orders, does not harm the third party, and does not cause damage to third parties, whether or not the complainant, the defendant, or any other person. For example, the performance of testimony is permissible and legitimate and not prohibited by the legislator. The witness was committed to honesty without causing any legal breach resulting in harm to the parties of the dispute or the case. So he will not abuse him, whether by slander, humiliation, assault, threats, extortion, compromise, false testimony, failure to appear as a witness, or refusal to answer one or more questions addressed to him during the hearing of his testimony or other acts.

\subsection{Elements of the Personal Liability of the Witness to the Unlawful Act}

The elements of the personal liability of the witness to give a statement or failing to testify are as follows:

A) The unlawful act (harm): In general, the unlawful act is defined in the explanatory notes to the Jordanian Civil Code ${ }^{25}$ in article 256 of this law ${ }^{26}$ : "Damage is a civil liability even if it is made by a non-privileged person, and that the term harm in accordance with the provisions of Article 256 of the Civil Code is sufficient and exempt from all other denominations and such as the terms of illegal, wrongful action or act prohibited by law and other terms.

Based on the above, and since the damage is the first element of personal liability, which is the unlawful act, it follows that this element is also the first element of the personal liability of the witness for his harmful action, which is the area of his personal liability, This area must be affected by any illegal action against third parties.

Damage in this respect is defined as: "exceeding the limit to which the duty is to be placed or the limit to be reached in the act or omission which causes the damage ${ }^{27}$.

Undoubtedly, harm in accordance with the above meaning is different from the concept of damage in general. Moreover, this concept is not synonymous at all. The proof is that the damage was an unlawful act of the witness, such as his failure to perform the testimony without any legitimate justification, either complete or partial abstention. Or blackmail whom is required to testify in order not to testify unless he receives a benefit from it, or such as insulting, defaming, one of the parties of the case or the lawyers who are prosecuting the case. The damage is the harm or negative effect resulting from the wrongful act of the witness. The affected third party, remains in existence even if he has no intention of harm. The reason for this is the liability of a purely objective nature and does not consider any factor or personal element related to the will of the perpetrator or recognition or discriminating his intention or awareness of the consequences of his action ${ }^{28}$. Accordingly, in the light of the foregoing, the basis for the liability of the witness for personal error requires commitment of a damage or wrongful act and this wrongful act may be the result of refrain from the testimony, Insulting, threatening, extortion, abuse of trust, forgery, beatings, destruction of a document, defamation of the court, breach of the court's rules, violation of the court system, etc., and may stem from civil law such as assault of name, character, reputation, financial consideration, social status, etc., or any other applicable and enforceable law that provides for the non-performance of a wrongful act. The witness shall do so. It is necessary to state in this regard the most important illegal acts envisaged by the witness the right of damage to third parties, namely:

1) To include in his testimony statements that violate the dignity, honor, integrity, arrogance, objectivity, or acquittal of a party, the lawyers, the court or third parties, or to commit, libel, defame, insult or harm his private life: as stating that he is a criminal, dangerous, despicable, ignorant, unjust, racist, stupid, ignorant, incompetent, useless, mistrustful, harassing, dishonest, dishonorable. In essence, the testimony constitutes an accusation, without having been asked about any matter that should mention such statements.

2) to mention false statements: such as attesting that the defendant did not beat, steal, threaten, defame or bribe the plaintiff or offer him a bribe. His testimony is false and incorrect, i.e., the defendant committed the offense

\footnotetext{
${ }^{25}$ See Explanatory Notes on Jordanian Civil Law, Publications of the Technical Office of the Jordanian Bar Association, 1992, I, 3c, 1, p. 275 .

${ }^{26}$ Article 256 of the Jordanian Civil Code stipulates that: "Any damage to third parties is required by the actor and not to be distinguished by ensuring damage.

${ }^{27}$ Explanatory notes, op. Cit., P. 277.

${ }^{28}$ Adnan Al-Sarhan, Nuri Khater, Explanation of Civil Law, op. Cit., Pp. 378-379.
} 
represented by any form referred to and not as said by the witness in his testimony, or to say in his testimony that the defendant is not indebted to the plaintiff with any amount. While the defendant is definitely liable to pay the plaintiff and not as said by the witness. The witness is aware and know that the defendant is indebted to the plaintiff but because of malicious or revenge reasons against the plaintiff he made false testimony.

3 ) If the witness refrains from appearing for testimony without legitimate excuse. In this case, the witness knows that he is required to appear before the court to perform his testimony, but he refuses to appear either for the opponent favor, or revenge from a party in the case. This act may cause damages to the rightful party who may incur the fees and expenses of his lawyers, so that such damage would not have occurred if the witness did not refrain from attending and performing his testimony.

4) If the witness appears in the court, but refrains from performing the full testimony or to respond to one or more questions addressed to him, without having a legitimate excuse. In this case his action is unlawful and his liability may cause harm to the injured party, who may be the plaintiff or the defendant in the legal or religious case, or the complainant in the criminal case. For example he may be asked a question about an incident and he is the only witness but refrains from answering this question without a legitimate justification

B) Damage: Damage is the second element of the personal liability for the unlawful act. The harm in general is what affects a person's right or legitimate interest ${ }^{29}$, or the harm suffered by others, either in their money, their feelings, freedom or consideration ${ }^{30}$ it is the damage that affects him by the violation of their rights or interest related to his or her property, passion, freedom, honor, respect or physical health. ${ }^{31}$ The damage resulting from the wrongful act of the witness can be defined as (A) the injury to which one of the parties to the case or its claimants, the court or a judge's agent, or a third party of the witness unlawfully and whether this unlawful act infringes the offer, honor, dignity, reputation, consideration or financial position of that person, his rights guaranteed and covered by legal protection or interest of his draft decision).

This damage may be material, which is expressed as financial or economic damage because it impairs the material right, money or indemnity to the injured person. ${ }^{32}$ For example, the testimony of the witness will result in a loss of the right of the plaintiff, where the witness says wrongfully that the defendant is not indebted to the plaintiff, or that the defendant did not receive the goods from the plaintiff while he definitely knows that the defendant received it . Or to falsely testify that the defendant did not borrow objects or material of high material value from the plaintiff. This damage may be a moral non-financial damage. ${ }^{33}$ Because it does not affect the financial liability of the victim of the wrongful act of the witness, but rather it affects his honor, dignity, reputation, or social status. For example, the witness, insulting of the defendant, or accusing the company belonging to him of dealing only of smuggling, or is about to be bankrupt or under liquidation or insolvency and a burden of debts, or accusing this company is a promoter of prohibited anabolic, or harmful to health and murder, toxic or carcinogenic agents.

It should be said that such damage, in order to be compensable, must satisfy several conditions:

1) The damage shall be established and confirmed: it is intended to be fixed as certain and confirmed. It is so if it occurs actually and really, and in this sense the current damage either if it is a loss suffered by the victim or missed gain ${ }^{34}$.

2) The damage is direct: ${ }^{35}$ this means that the damage is a direct result of the wrongful act of the witness, so that it is not possible to say the injured person may be compensated for the damage caused by the wrongful act.

3) Damage affects a legitimate interest of the injured person. ${ }^{36}$ In this respect, the damage must be a legal right or a legitimate interest of the wrongdoing of the wrongful act so that such damage may be compensated

\footnotetext{
${ }^{29}$ Abdel-Moneim Farag al-Sadah, Sources of Commitment, A Study in Lebanese and Egyptian Law, Dar al-Nahda al-Arabiya, Cairo, 1, 1979, p. 485.

${ }^{30}$ Abdel Hakim Fouda, Civil Compensation (Civil Liability Contractual and Conviction), in the Light of the Jurisprudence and Judgments of the Court of Cassation, University Publications House, Alexandria, 1989, p. 17.

${ }^{31}$ Abdul Aziz al-Lasamah, Civil Liability for Tort (The Harmful Action), Its Basis and Conditions, Dar Al-Thaqafa, Amman, 1, 2002 , p. 63.

${ }^{32}$ Adnan Al-Sarhan, Nuri Khater, Explanation of Civil Law, op. Cit., P. 410.

${ }^{33}$ See Article 267/1 of the Jordanian Civil Code, which has addressed and regulated this type of damage.

${ }^{34}$ Abdul Majeed al-Hakim, Abdul Baqi Bakri, and Mohamed Taha Al-Bashir, Civil Law, Provisions of Commitment, C2, Publications of the Iraqi Ministry of Higher Education and Scientific Research, Baghdad, p. 528.

${ }^{35}$ Abdul Majid al-Hakim, Abdul Baqi Bakri, and Mohamed Taha Al-Bashir, Civil Law, Provisions of Commitment, C2, Publications of the Iraqi Ministry of Higher Education and Scientific Research, Baghdad, p. 528.

${ }^{36}$ Saadoun Al-Ameri, Compensation for Damages in Tort Liability, Publications of the Legal Research Center, Baghdad, 1981, p. 19.
} 
C) Causality: The third and last element of the personal liability of the witness is the causality relationship. It is not sufficient to hold the witness liable for an unlawful act that resulted in harm and injury of the victim. Rather, the wrongful act must be the cause of the occurrence of the damage. This is expressed in the causal relationship between the wrongful act and the damage, which is definitely comply with the logic and the provisions of Article 256 of the Jordanian Civil Code, which states: "any injurious conduct shall render his perpetrator liable to compensate its harms regardless of any fault". It should be noted that the judge, through written and personal statements presented to him, determines and decides whether the causal relationship has taken place between the wrongful act and the damage. It is not clear that the burden of proof of the causal relationship rests with the person affected by the act of the witness. And since he is the plaintiff in the lawsuit of liability and claim of loss and damage caused by the witness. The witness is entitled to prove that there is no causality relation existing. The matter is subject to legal evidence. The question raised in this respect is: Which theory of causation adopted by the legislator in this regard? Is it the theory of equivalence of causes or the theory of the strongest cause or the theory of productive or effective cause?

The answer to the previous question found in the text of Article 266 of the Civil Code, which states:

"The court may award the plaintiff damages that cover the actual damage he sustained as well as the lost profit provided that such damage and loss are the natural result of the defendant's conduct"

The last part of this provision, in particular the latter part, requires that the damage be direct so that it can be compensated, that is, the damage is the result of the wrongful act, and therefore the theory of the active or productive reason is the theory adopted by the Jordanian legislator in this area. ${ }^{37}$

\subsection{Forms of the Harmful Act of the Witness}

There is no doubt that the forms of the harmful act of the witness are multiple and varied, since the harmful action resulting from his testimony, or the result of his image as a witness, does not have a single form, but has several ones, which can be summarized as follows:

\subsubsection{The Witness Give False Testimony}

In this regard we are facing two cases: the first in the field of criminal, legal and religious cases. And second in civil and commercial proceedings. The details are as follows:

A) False testimony in criminal, legal and religious cases:

In this case, the witness is before the criminal, legal or religious court, or the prosecutor, and he attests to a testimony which is then proved false, whether he denies the whole truth in his testimony, or part of it, or mute facts, or any known facts of the case ${ }^{38}$.

Here, the witness when giving a false testimony is considered a form of the harmful act because his false testimony causes damage to the third party, whether the third party is the complainant or the defendant in the criminal case or the plaintiff or defendant in the legal or religious case.

\section{Practical examples of perjury include:}

- The witness falsely testifies that the defendant stole the complainant's money.

- The witness falsely testifies that the defendant did not hit the complainant.

- The witness gives a false statement in a Shariah case the subject of divorce due to dispute that the defendant (husband) repeatedly beats his wife, not paying her living expenses, or to testify that the wife is shrew and return home late at night, or have a lover.

Here, the victim of a false testimony is entitled, and if having a supporting evidence to sue the witness and claim for compensation.

B) False testimony in civil and commercial proceedings:

In this case, the witness is in the civil or commercial case, whether he is a witness to the plaintiff or the defendant to give false testimony. If he is a witness to the plaintiff in a claim for labor rights, and denies in his testimony that the plaintiff was working on Fridays, official and religious holidays, working overtime, and then proving that his testimony was false, or if he gives a false statement for the interest of the defendant's stating that the plaintiff was not employed at the defendant. Or if he mentions in his false testimony and for the purpose of

\footnotetext{
${ }^{37}$ Adnan Al-Sarhan, Nuri Khater, Explanation of Civil Law, op. Cit., P. 455.

${ }^{38}$ The legislator has regulated the provisions of perjury in all cases in articles 214-217 of the Jordanian Penal Code No. 16 of 1960 and its amendments.
} 
obtaining a large amount of compensation by the plaintiff that the plaintiff has a well-known reputation and high social status, and that he is honest man, does not take drugs, and has no criminal record, and that after insulted by the defendant he was admitted to the hospital and suffered of acute psychological depression and mental damages. If after that, his testimony was proven to be false, since the plaintiff was not suffering any of the sayings alleged by the witness, and that the plaintiff was in prison and not in a hospital as mentioned, and that he is a promoter and drug abuser.

Here, undoubtedly, the perjury of the witness is considered harmful, and the injured person has the right to sue and challenge him at Court and to claim compensation for the damage caused by his false testimony.

Finally, it is important to state that the plaintiff when filing a lawsuit against the witness for the perjury, and claims for compensation, must prove to the court that the witness has been judged with a final penal judgment stating that he committed the crime of perjury or that the witness confirms before the court that he actually gave a false testimony.

\subsubsection{The Witness Deliberately Decides not to Appear for Testimony}

In such a case, the witness is required for giving his testimony in a legal, penal or personal case. But, he avoids the procedures of service of notice and refuses to give his testimony filed by the opponent who requested his statement. If the members of the public security - judicial police - cannot find him and bring him to the court to hear his testimony.

The court then decides whether the opponent has failed to bring the witness, or decides on the basis of the report of the judicial police, regardless of his testimony, if the case is penal and if he has a testimony before the general prosecutor at the investigation stage. If there is no testimony, then no reason to call him.

In this regard, no doubt the opponent who requested this witness who deliberately did not to appear may be harmed by the intentional act of the witness who insists not to attend. He shall have the right to sue and challenge this witness at the court and to claim compensation for damage caused by his wrongdoing. The act of the witness here is considered illegal, for his intentional behavior and denial to give his testimony. It is also an illegal act, because the main element of the wrongful act is violating the lawful obligation which requires and warrants not to violate a legal provision and not to harm others. The witness deliberately did not appear for testimony in violation of the order of the legislator, which requires him to give the testimony. If the witness has an excuse preventing him to appear before the judge and he presents and proves such absence and found to be legitimate and justified, and convincing to the judge, the Judge will exempt him from giving his testimony.

But if the witness intentionally being absent and fails to give his testimony, without legal excuse and the consequences affecting one of the litigating parties, then his act is considered illegal and becomes under liability.

Especially that such testimony of this witness would be a saving factor of the litigating party requested the witness, whether to avoid imprisonment, civil obligations, legitimate obligations or otherwise. Definitely absence of the witness to give his testimony will cause harm to that party.

In this case, the opponent, when suing this witness, must prove to the court before which the civil liability case is filed, that the witness did not appear deliberately. This witness is entitled to prove to the court that the opponent has not been harmed or that he has his own excuses to be absent. The matter will be subject to legal proof. In other words, if the witness intentionally be absent to give the required testimony, and such act is legally proved. In addition to proven damages affecting the opponent due to witness absence, makes the witness act as illegal and a legal reason to sue him claim for compensate for damages.

\subsubsection{To Witness Shall Give His Testimony on Facts Prohibited to Be Testified}

According to this case, when a witness is summoned and asked to testify, the witness must tell the judge, the prosecutor or the judicial authority which called him to testify that he cannot legally testify because there is a legal impediment to performing the testimony. If, however, he did not advise such parties of this reason and presented his testimony, the affected party has the right to challenge him and claim for compensation for the caused damages. It should be noted that persons who are legally prohibited from performing the testimony are:

\section{1) Staff, Employees and Public Servants ${ }^{39}$}

Any staff, employee or public service officer is not legally entitled to give a testimony of information obtained during the course of his public service, and this information is related to a pending case and requested to give his testimony on this information. This prohibition remains either he is on duty or left public service for any reason,

\footnotetext{
${ }^{39}$ This case is provided for in article 36 of the Evidence Act.
} 
unless authorized by the competent authorities to testify on such information.

Accordingly, if such staff, employee or public service officer gives a statement of information learned from his public official work, and does not obtain the approval or authorization of the competent authorities to perform the testimony on this information which resulted in damage to one of the parties of the case, the affected party is entitled to challenge him and claim for compensation.

An example of this case is that if the plaintiff has filed a claim for compensation against a public institution due to termination of his contract and failure to pay him his entitlements and he alleged that the reason for the termination of the contract is not due to legal reasons, and that he was materially and morally damaged from such termination, and requested among his evidences to hear the testimony of a particular employee in that public institution, who knows the real reason for termination of his contract. When that employee appeared he gave his testimony without taking the prior approval of the competent authorities (the institution where he works). In his testimony, he stated that the reason for terminating the plaintiff's contract is because he is corrupt and negligent and is subject to many corruption suspicions. Here the plaintiff has the right to sue this witness and claim for compensation, because he gave a testimony without obtaining the consent of the competent authorities, and his testimony resulted in damage to the plaintiff. The public institution may sue the witness and claims compensation if he states in his testimony that the reason for termination of the plaintiff's contract is not based on the basis of the law or the facts, and that the Director of that public institution appoints his friend in place of the plaintiff. The public institution, being damaged by this testimony, has the right to sue this witness and claim compensation for the damage caused by his testimony, especially since he gave his statement without taking the prior consent of the institution.

2) Lawyers, Agents and Doctors ${ }^{40}$

In this case, lawyers, agents and doctors are legally prohibited from giving any testimony about any information they obtained during their service, even if his relationship, status or work with the intended person has ended.

For example, if there is an action against a client appointing an attorney and the plaintiff requests to hear the testimony of the plaintiff's attorney (the advocate), the attorney must refrain. The same is true of the doctor, the public or private agent, and whenever any of these persons testify, the injured person, who is here with the lawyer or the agent, or the patient with the doctor, may file a civil action to claim compensation for the damage caused by this testimony, Performance.

It goes without saying that the legislator's objective is to prevent them from carrying out the testimony, in order to protect the secrets of the profession, even though the legislator does not define the meaning of professional secrecy. This is a deficiency that must be corrected by defining the purpose of professional confidentiality. The rest of the professions are from accounting, business administration, nursing, pharmacists, etc. The heads of these professions are not covered by the ban, which is a deficiency that must be remedied by adding to them

In addition, lawyers or agents are not entitled to testify against any wrongful acts committed by their client, what rights they have engaged in, etc., such as a professional secret. It is also not possible for the doctor to give a testimony stating the health or psychological condition or pathology of the patient, or other matters in the confidentiality of the profession. When any of these testimony s, the client may have the lawyer, or patient with the doctor, to sue He exposed his secrets and caused him harm.

3) Spouses $^{41}$

It is not lawful for a husband or wife whenever one of them files a lawsuit against the other to testify against each other, whether the husband or wife. Unless there is a prior consent and acceptance, even if the marital relationship between them has been dissolved.

Therefore, if there is an action against the husband, and the defendant requests that the wife to give her testimony on a particular matter or matters that she learned because the wife of the plaintiff or his wife, attended and gave her testimony without consent and acceptance of her husband, her husband has the right to sue her and claims for compensation for damages affecting him due to the wife's testimony. Since law requires consent of the husband for his wife to give her testimony, and since such as not issued by him.

It is noted that the purpose of the legislator of prevention is to protect the secrets of the couple, but we note that the prohibition is limited to couples whether the relationship exists or ended, and does not include the prohibition of sinners so it would be better if the legislator forbade those who are in a period of engagement, especially since

${ }^{40}$ Article 37 of the Evidence Act.

${ }^{41}$ Article 38 of the Evidence Act. 
this period may be prolonged, One of them is required to testify and cannot abstain because there is no legal text that he can abstain from, and the performance of the testimony leads to termination of the betrothal between them by leaving, resulting in damage to both.

We also urge the legislator to prevent the testimony between the assets and branches unless there is prior consent and consent in order to limit the negative effects that may result from the performance of the testimony, and the inability of the witness to refrain from performing the testimony because there is no legal text that allows him to refrain

\subsubsection{The Witness Refuses to Give the Testimony or Answer Questions ${ }^{42}$}

Under this form, the witness appears in the court. When he is required to testify, or to answer questions he refuses without giving reasons satisfactory to the court.

The victim has the right to make this witness, whether plaintiff or defendant, a complainant or a complainant to section that the witness compensate for the damage caused to him by his refusal to testify or answer questions.

For example, the plaintiff may request the witness to hear his testimony about the material and moral damage that he has suffered from the defendant's act, but if the witness refuses to perform the testimony in full or refuses to answer questions from the plaintiff or his agent without giving reasons for his refusal.

\section{Conclusion}

This study deals with the subject of civil liability of the witness in the Jordanian civil law, which resulted in a set of conclusions and recommendations, which are as follows:

\subsection{Results}

1) A witness is a natural person who attends the Judicial session to give his testimony with information about a particular event that he has seen or heard himself or recognized by one of his senses, or learned from others, and is different from the expert and the agent of the bankruptcy, the complainant and the plaintiff.

2) The witness may help to achieve justice and may work to harm it.

3) The liability of the witness for the harmful act is raised and existed when he violated a previous legal obligation, requires him not to commit such breach, and yet he committed it. The content of the obligation here is that the damage is not only to cause illegal damages to third party, but even so he commits such damages. Therefore the damage made by him, characterized as illegal is the source and origin of his liability.

4) The liability of the witness for the harmful act is when he performed the testimony illegally or contrary to the law or refrained from performing the testimony in full or parts thereof. Here he committed an illegal act harmful to others. Therefore, this liability is punishment against the behavior of a witness who has violated the legal rules imposed on him, which obliges him not to harm others, regardless of the capacity of the other person. It also takes place when the witness does not comply with the truth and does not adhere to the principles of honesty, impartiality, objectivity and respect for others or when he denies good morals, customs, traditions, values, controls and principles of the performance of the testimony. It is also the case that when a witness violates or neglects or breaches the law which requires him to refrain from unjustified refraining from performing the testimony. Or presenting a false testimony, obtaining a bribe in return for the performance of the testimony, insulting, defaming, one of the lawsuit parties. It is not wrong that this liability is committed when the witness has the honor, impartiality, integrity and impartiality of the complainant or any other person without a right and without directing Ask him any questions about these things.

5) One form of the harmful act of the witness when he indicates in his statement incorrect words, or if he fails to appear to give his statement without legal excuse, or if the witness attends the court, but despite his appearance he refrains from performing the full testimony or to respond to one or more questions addressed to him, or if A testimony which is prohibited from its performance resulted in damage inflicted on one of the litigants.

6) The elements of the harmful act of the witness are the occurrence of an unlawful act, the damage caused by the act and a causal link between the wrongful act and the damage. The damage is required until compensation is accepted, the damage is direct and the damage is a legitimate interest of the injured party.

\subsection{Recommendations}

In accordance to the presence of shortages, lack and ambiguity on the civil liability of the witness, we urge the Jordanian legislator to:

${ }^{42}$ Article 165 of the Code of Criminal Procedure and Article 8 of the Violation of Courts Law No. 9 of 1959. 
1) Working on the definition of the witness, especially in the law of evidence, in the absence of any legal provision defines the meaning of the witness.

2) To address the question of the witness's denial of his statement in civil and commercial proceedings where the legislator did not resolve this issue but only in the context of criminal proceedings, and this is so as not to pursue a witness for his false testimony thereafter.

3) Regulating the civil liability of the witness independently and individually in view of the importance of this subject.

4) Defining false testimony, especially as it is a form of harmful act of the witness.

5) Reconsideration of the persons who are legally prohibited from performing the testimony by adding all the professions, crafts, industries, jobs, assets, branches, and those who are invited.

6) To define the forms of the harmful act of the witness: to give false testimony or intentional absences to give a testimony, or testimony of which is prohibited: or refrain from performing the testimony.

7) Definition of the professional secret, because the legislator did not define its meaning. a dispute may arise on its meaning especially when considering the liability of the witness, especially if he is of a professional career.

\section{References}

al-Dinasuri, I. al-D., \& Akkaz, H. A. H. (1977). Commentary on the Law of Evidence. World of Books, Cairo.

Al-Douri, S. (1997). Certificate in Islamic Law and Law, Master's Thesis, Faculty of Law, University of Babylon.

al-Hakim, A. M., Bakri, A. B., \& al-Bashir, M. T. (n.d.). Civil Law, Provisions of Commitment, C2. Publications of the Iraqi Ministry of Higher Education and Scientific Research, Baghdad.

Al-Lusamah, A. A. (2002). Civil Liability for Tort (The Harmful Action), its Basis and Conditions. Dar Al-Thaqafa, Amman.

Al-Sadah, A.-M. F. (1979). Sources of Commitment, A Study in Lebanese and Egyptian Law. Dar Al-Nahda Al-Arabiya, Cairo.

Al-Sanhoury, A. R. (n.d.). The Mediator in the Explanation of Civil Law, Part II Theory of Commitment in General, Evidence, Implications of Commitment. House of Revival of Arab Heritage Beirut.

Al-Sarhan, A., \& Khater, N. (2000). Explanation of Civil Law, Sources of Personal Rights. Dar Al-Thaqafa, Amman.

Al-Shawarbi, A. (1996). Evidence of Witnesses in Civil, Commercial, Criminal and Personal Status, Knowledge Establishment, Alexandria.

Al-Zu'bi, A. A. (2003). Principles of Civil Trials. Dar Wael Publishing, Amman.

Bakush, A. R. (1998). Evidence of evidence in the Algerian law and Islamic jurisprudence, a theoretical and applied study. publications of the National Book Foundation, Algeria.

Cherkaoui, J. (1983). Evidence in Civil Subjects. The Arab Renaissance House, Cairo.

Civil Law No. 43 of 1976.

Decisions of the Court of Cassation published on Adalah's website.

Eid, E. (1991). Encyclopedia of the Foundations of Trials, Evidence and Implementation, Part Sixteen, Proof (Right and Testimony). Without Publishing House, Lebanon.

Fouda, A. H. (1989). Civil Compensation (Contractual and Compulsory Civil Liability), in the Light of Jurisprudence and Cassation Law. University Publications House, Alexandria.

Gregg, K. (1996). The General Theory of Obligations, Part III in Proof of Obligations (System of Evidence). Al-Saad Printing Press, Beirut.

Hassanein, Y. (1997). Evidence in the Algerian Civil Code. Publications of the National Book Foundation.

Hijazi, M. A.-J. (2004). Civil Liability of the Judicial Expert. New University House, Alexandria.

Mark, S. (1986). The Origins of Evidence and its Procedures in Civil Law in Egyptian Law, in Comparison with the Techniques of the Arab Countries (Part Two). The Restricted Evidence and What Can Be Proved in Writing, Dar Al-Jail for Printing, Cairo. 
Nafi, M. (2008). Explanation of the Jordanian Evidence Law. Without publishing house, Amman.

Najm, M. S. (2002). Code of Criminal Procedure (1st ed.). Dar Al-Thaqafa, Amman.

Nashat, A. (1972). The anchor of evidence, Part I, Elements of evidence, the burden of proof, methods of proof, writing, witness testimony. Arab Thought House, Cairo.

Ragheb, M. A. (1960). The General Theory of Evidence. Knowledge Press, Cairo.

Soldier, A. M. (1931). Criminal Encyclopedia, Part I (Trading, Subscription). Egyptian Book House, Cairo.

Sultan, A. (1984). Rules of Evidence in Civil and Commercial Law, A Study in the Egyptian and Lebanese Laws. University House, Beirut.

The Civil Procedure Law and its amendments No. 24 of 1988.

The Evidence Law and its amendments No. 30 of 1952.

The Law of Criminal Procedure and its amendments No. 9 of 1961.

The Penal Code and its amendments No. 16 of 1960.

Trade Law and its amendments No. 12 of 1966.

Violation of the Courts Law No. 9 of 1959.

\section{Copyrights}

Copyright for this article is retained by the author(s), with first publication rights granted to the journal.

This is an open-access article distributed under the terms and conditions of the Creative Commons Attribution license (http://creativecommons.org/licenses/by/4.0/). 